Web Jurnal:

http://ejournal.kemenperin.go.id/jli

\title{
Analisis statistik performa turbin angin vertikal dengan slotted blades
}

\section{Statistical analysis of slotted blades vertical axis wind turbine performance}

\author{
Catur Harsito*1, Dominicus Danardono Dwi Prija Tjahjana ${ }^{2}$, Budi Kristiawan ${ }^{2}$ \\ 1 Vokasi Teknik Mesin, Universitas Sebelas Maret \\ J1. Ir. Sutami No.36 A, Surakarta, Jawa Tengah, Indonesia \\ 2 Teknik Mesin, Fakultas Teknik, Universitas Sebelas Maret \\ Jl. Ir. Sutami No.36 A, Surakarta, Jawa Tengah, Indonesia \\ * e-mail: catur_harsito@staff.uns.ac.id
}

\begin{tabular}{l}
\hline INFO ARTIKEL \\
\hline Sejarah artikel: \\
Diterima: \\
29 September 2020 \\
Direvisi: \\
03 Juni 2021 \\
Diterbitkan: \\
30 Juni 2021 \\
\end{tabular}

\section{Kata kunci:}

VAWT;

slotted blades; analysis of variant; factorial design

\begin{abstract}
ABSTRAK
Energi terbarukan merupakan energi alternatif yang bersih, bebas polusi, aman dan ketersediaanya tidak terbatas. Energi angin merupakan salah satu energi terbarukan. Pemanfaatan energi angin dilakukan dengan menggunakan turbin angin salah satunya savonius. Turbin savonius memiliki kekurangan pada nilai koefisien daya ( $\mathrm{Cp}$ ) yang rendah. Penambahan konfigurasi posisi dan lokasi slotted blades dapat meningkatkan nilai $\mathrm{Cp}$. Untuk memaksimalkan desain turbin angin savonius maka perlu dicari faktor yang paling berpengaruh terhadap nilai $\mathrm{Cp}$. Penelitian ini bertujuan untuk menganalisis signifikansi unjuk kerja turbin angin savonius dengan konfigurasi slotted blades secara statistik. Pengujian hipotesis dari dua faktor yang mempengaruhi nilai $\mathrm{Cp}$ dilakukan dengan menggunakan metode pengujian statistik Kolmogorov Smirnov Test, Normalitas test, analysis-of-variance (ANOVA) linier, one-way ANOVA menggunakan software SPSS 22. Hasilnya menunjukkan bahwa lokasi slotted blades berpengaruh secara signifikan terhadap nilai Cp (Sig. 0,000 kurang dari 0,05). Terdapat interaksi antara kedua variabel uji posisi*lebar (Sig. 0,000 kurang dari 0,05). Posisi slotted blades lebih berpengaruh signifikan terhadap nilai $\mathrm{Cp}$ karena nilai Sig. 0,000 lebih rendah dari lebar slotted blades 0,011 .
\end{abstract}

Keywords:

VAWT;

slotted blades;

analysis of variant;

factorial design

\begin{abstract}
Renewable energy is an alternative energy that is clean, pollution-free, safe and has unlimited availability. Wind energy is one a renewable energy. The utilization of wind energy is done by using wind turbines, one of which is Savonius. Savonius turbines have a disadvantage in low Coefficient power ( $\mathrm{CP}$ ) values. Adding the configuration of the position and location of the slotted blades can increase the Cp value. To optimize the design of Savonius wind turbines, it is necessary to find the factors that most influence the $C p$ value. This study aims to analyze the significance of the performance of slotted blades savonius wind turbines with statistically. Hypothesis testing of two factors that affect the value of $\mathrm{Cp}$ is done using the statistical method, Kolmogorov Smirnov test, linearity test, linear analysis-of-variance (ANOVA), one-way ANOVA using SPSS 22 software. The results show that the location of slotted blades significantly influences the location of slotted blades to the value of CP (Sig. 0.000 less than 0.05). There is an interaction between the two position test posisi*lebar (Sig. 0.000 less than 0.05). The position of the slotted blades has a more significant effect on the value of Cp because of the value of Sig. 0.000 lower than the width of the slotted blades of 0.011.
\end{abstract}

(C) 2021 Penulis. Dipublikasikan oleh Baristand Industri Padang. Akses terbuka dibawah lisensi CC BY-NC-SA

\section{Pendahuluan}

Energi terbarukan merupakan energi alternatif yang besih, bebas polusi, aman dan ketersediaanya tidak terbatas (Akhmad, 2005). Penggunaan sumber energi terbarukan mengalami peningkatan menuju $23 \%$ dari total penggunaan energi nasional 2003-2020 menurut Kebijakan Energi Nasional Indonesia (KEN) (Nugroho, 2013). Energi angin merupakan salah satu sumber energi terbarukan. Energi angin memiliki sumber energi yang melimpah dan popular sebagai sumber energi alternatif diantara sumber energi terbarukan lainnya seperti solar 
energy, biomass energy, dan geothermal energy (Ramadhan et al., 2016; Morshed, 2010). Namun, energi angin yang dimanfaatkan menggunakan turbin angin memiliki beberapa kekurangan yaitu biaya instalasi yang tinggi dan perlunya angin kencang untuk menghasilkan listrik.

Berdasarkan arah aliran anginnya turbin angin dibedakan menjadi dua macam yaitu turbin angin sumbu vertikal dan turbin angin sumbu horizontal (Tian et al., 2018). Penggunaan turbin angin sumbu vertical lebih banyak digunakan untuk turbin skala kecil dikarenakan memiliki beberapa keunggulan yaitu kinerjanya tidak tergantung arah angin (Akwa et al., 2012), mudah dalam perawatan (Yang and Lawn, 2011), dan juga dapat beroperasi pada kecepatan angin rendah (Jha, 2010). Selain itu, turbin angin sumbu vertikal memiliki keunggulan start-self yang tinggi dan dapat beroperasi pada kecepatan rendah, memiliki torsi yang tinggi, dan memiliki noise yang kecil (Montelpare et al., 2018). Keunggulan itu dimiliki oleh turbin angin sumbu vertikal tipe savonius. Namun, turbin angin savonius memiliki kekurangan yaitu efisiensinya yang rendah (Akwa et al., 2012).

Performa turbin angin savonius dipangurhi oleh beberapa faktor seperti bentuk blade, gap ratio, overlap ratio, jumlah blades, penambahan endplate, dan aksessoris lainnya. Penambahan slotted blades menjadi salah satu cara untuk meningkatkan performa turbin angin savonius. Alaimo et al., (2013b) melakukan penelitian tentang penambahan slotted blades yang disimulasikan menggunakan CFD (Computational Fluid Dynamics).

Pada penelitian eksperimental yang memiliki dua faktor atau variasi, hasil penelitiannya akan dipengaruhi oleh interaksi antara dua faktor atau variasi itu (Salomon et al., 2017). Interaksi dari dua faktor ini dapat diketahui dengan analisis statistik, dengan hasil analisis itu maka faktor yang paling mempengaruhi dapat diketahui (Arifianto et al., 2014). Salah satu Analisis statistik untuk melihat interaksi yang berpengaruh signifikan dilakukan dengan metode analisys of variance (Al Sadi, 2018). Interaksi yang berhasil diketahui sebagai faktor yang paling berpengaruh maka dapat digunakan dalam konfigurasi perancangan produk (Montgomery, 2017).

Penambahan slotted blades dapat meningkatkan performa turbin angin savonius. Oleh karena itu, dalam penelitian ini melaporkan pengaruh penambahan konfigurasi slotted blades secara statistik dan melaporkan faktor yang paling dominan terhadap nilai performa yang dihasilkan.

\section{Metode}

Penelitian ini dilakukan secara eksperimen di laboratorium termodinamika. Spesimen uji dibuat dengan bahan alumunium dengan ketebalan $3 \mathrm{~mm}$ dengan bentuk seperti pada Gambar 1. Pengambilan data dilakukan dengan melakukan pengulangan lima kali setiap variasi pengujian. Setelah dilakukan pengujian secara eksperimen, kemudian dilakukan analisis secara statistik untuk melihat interaksi dan juga pengaruh dari masing variasi ataupun hubungan kedua variasi. Pada penelitian ini untuk menghasilkan nilai daya, maka menggunakan rumus teori daya turbin dan juga torsi pada sistem prony brake

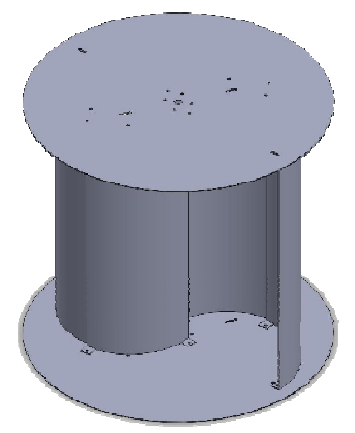

Gambar 1. Spesimen turbin angin savonius

\section{Dasar teori}

Nilai daya dapat diketahui dengan cara menghitung nilai torsi yang terjadi pada turbin. Nilai torsi pada turbin dihitung menggunakan sistem prony brake.

\subsection{Daya turbin}

Daya turbin merupakan daya mekanik yang dihasilkan oleh rotor (P). Berdasarkan (Tjahjana et al., 2021) nilai daya turbin dapat dihasilkan dengan menggunakan rumus (1). Nilai daya turbin ini dapat diperoleh apabila nilai torsi yang bekerja pada turbin diketahui. Nilai torsi ini dapat diketahui dengan menerepkan sistem prony brake (Gambar 2.).

$$
P=T \cdot \omega
$$

dimana $\omega$ adalah putaran rotor turbin dan $\mathrm{T}$ adalah torsi pada poros. Karena nilai $\omega$ adalah $\mathrm{rad} / \mathrm{s}$ sedangkan hasil yang didapatkan pada pengujian adalah nilai rpm, maka hasil perhitungan $\mathrm{rad} / \mathrm{s}$ dikonversi dengan rumus (2). Hal ini dilakukan untuk mempermudah perhitungan.

\subsection{Torsi}

$$
\omega=2 \cdot \rho \cdot \mathrm{N} / 60
$$

Torsi merupakan bentuk ekuivalen dari gaya linier yang menghasilkan rotasi atau bisa disebut dengan gaya rotasi. Nilai torsi dihasilkan dari gaya yang bekerja pada tuas dikalikan dengan jarak tuas terhadap titik tengah.

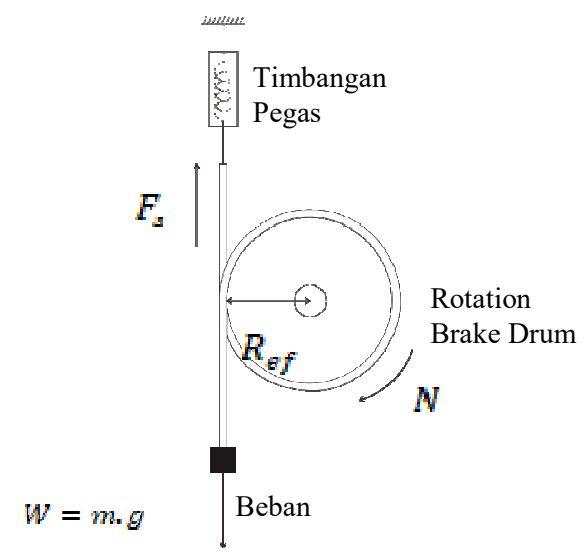

Gambar 2. Prony Brake System 
Torsi yang diukur merupakan daya yang bekerja poros turbin yang berputar. Pada penelitian ini, untuk mendapatkan nilai torsi menggunakan sistem prony brake seperti pada Gambar 2. Pada sistem prony brake ini, torsi didapatkan dari hasil perkalian antara gaya dengan jari-jari efektif (3). Nilai gaya yang bekerja didapatkan dengan menggunakan rumus (4) dimana massa pemberat dikurangi gaya yang terbaca pada timbangan. Radius efektif merupakan penjumlahan dari radius rotor dan radius tali (5).

$$
\begin{array}{r}
T=F_{e} \times R_{e f} \\
F_{e}=W-F_{z} \\
R_{e f}=R_{z}+R_{r}
\end{array}
$$

dimana $F_{e}$ (Newton) adalah gaya efektif yang bekerja pada system prony brake, $F_{s}$ (Newton) adalah gaya yang terukur pada timbangan pegas, $W\left(\mathrm{~kg} \cdot \mathrm{m} / \mathrm{s}^{2}\right)$ adalah beban yang bekerja, $R_{e f}$ (meter) adalah radius efektif, $R_{s}$ (meter) adalah radius poros dan $R_{r}$ (meter) adalah radius tali.

\subsection{Koefisien daya (Coefficient power)}

Koefisien daya merupakan nilai nondimensional dari perbandingan antara daya aktual turbin dibandingkan dengan daya total yang tersedia dari angin dirumuskan pada persamaan (6), dengan nilai $\mathrm{P}_{\mathrm{T}}$ (daya teoritik) yang dihasilkan dari perhitungan dengan menggunakan persamaan (7).

$$
\begin{aligned}
& C_{p}=\frac{P}{P_{r}} \\
& P_{T}=1 / 2 \cdot \rho \cdot A v^{2}
\end{aligned}
$$

dimana, $\rho\left(\mathrm{kg} / \mathrm{m}^{3}\right)$ adalah massa jenis udara, $A\left(\mathrm{~m}^{2}\right)$ adalah luas penampang area turbin, dan $v(\mathrm{~m} / \mathrm{s})$ adalah kecepatan angin.

\subsection{Koefisien torsi}

Koefisien torsi merupakan perbandingan antara torsi yang bekerja pada poros dengan torsi teoritis yang tersedia. Nilai koefisien torsi ini dirumuskan seperti pada persamaan (8).

$$
C_{t}=\frac{T}{r_{T}}
$$

dimana $T_{T}$ adalah torsi teoritis atau torsi mekanik total yang terkandung dalam angin yang melalui penampang turbin. Nilai torsi teoritik ini dirumuskan seperti pada persamaan (9).

$$
T_{T}=1 / 2 \cdot \rho \cdot A v^{2} R
$$

\subsection{Tip speed ratio}

Tip speed ratio (TSR) adalah merupakan perbandingan antara kecepatan ujung rotor terhadap kecepatan angin bebas.Nilai TSR didapatkan dengan menggukana persamaan (10).

$$
\lambda=\frac{\omega n}{y}
$$

dimana, $R$ adalah jari-jari turbin.

\subsection{Data}

Pengumpulan data dilakukan secara eksperimen dengan 2 variabel dan 3 level yaitu variabel posisi gap slotted blades dan lebar gap slotted blades. Pengujian dilakukan pada Reynold number $1,44 \times 10^{4}$ ditampilkan pada Tabel 1 .

Tabel 1

Variasi eksperimen.

\begin{tabular}{cc} 
Posisi Gap Slotted blades & Lebar Gap Slotted blades \\
\hline $20 \%$ & $3 \mathrm{~mm}$ \\
$30 \%$ & $5 \mathrm{~mm}$ \\
$40 \%$ & $7 \mathrm{~mm}$ \\
\hline
\end{tabular}

Posisi dan lebar celah gap slotted blades ditampilkan pada Gambar 3.

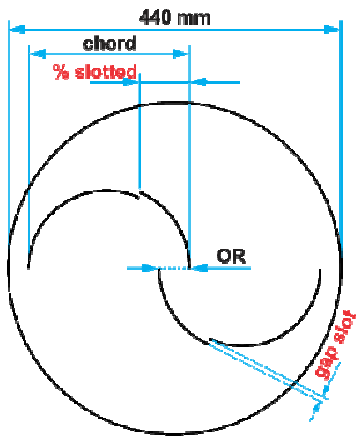

Gambar 3. Variabel eksperimen

\subsection{Alat uji statistik}

Pengujian signifikansi hasil $\mathrm{Cp}$ dilakukan dengan metode desain faktorial menggunakan perumusan hipotesis. Desain faktorial yang digunakan untuk menguji pengaruh penambahan konfigurasi slotted blades terhadap nilai $\mathrm{Cp}$ yaitu menggunakan analysis of variance (ANOVA) dengan tingkat kepercayaan $(\alpha) 95 \%$ atau 0,05 yang dianalisis menggunakan software SPSS Statistical 22 (Prasetyo and Bashit, 2018). Selanjutnya dilakukan analisis signifikansi dan faktor dominan berdasarkan hasil output pengolahan data dengan software SPSS dengan metode unvariate dan regresi linier berganda.

\subsection{Kolmogorov smirnov test}

Pengujian ini merupakan uji nonparametrik dan digunakan untuk mengetahui distribusi data yang dihasilkan (Rahman et al., 2018). Data dikatakan memiliki distribusi normal jika nilai signifikansi lebih besar dari 0,05. Sebaliknya, data dikatakan memiliki 
distribusi tidak normal jika nilai signifikansi kurang dari 0,05 .

\section{9. $A N O V A$ unvariated}

Pengujian ini dilakukan untuk mengetahui pengaruh variabel yang dilakukan (Mangedaby et al., 2017). Pengujian ini dapat dilakukan apabila sampel memiliki syarat yaitu sampel merupakan kelompok independent. Selain itu varian harus homogen serta data yang didapatkan memiliki distribusi normal.

Hipotesis pertama:

$\mathrm{H}_{0}$ : Faktor lebar slotted blades berpengaruh terhadap nilai koefisien daya.

$\mathrm{H}_{1}$ : Faktor lebar slotted blades tidak berpengaruh terhadap nilai koefisien daya.

Hipotesis kedua:

$\mathrm{H}_{0}$ : Faktor posisi slotted blades berpengaruh terhadap nilai koefisien daya.

$\mathrm{H}_{1}$ : Faktor posisi slotted blades tidak berpengaruh terhadap nilai koefisien daya.

\subsection{One-way $A N O V A$}

Selain dilakukan pengujian $A N O V A$ unvariated, dilakukan pengujian One-way ANOVA untuk melihat pengaruh antara dua variabel terhadap nilai $C p$. Pengujian ini dapat dilakukan ketika sampel yang ada merupakan sampel independen dan data yang tersajikan memiliki distribusi normal.

Hipotesis:

$\mathrm{H}_{0}$ : Faktor posisi dan lebar slotted blades berpengaruh terhadap nilai koefisien daya.

$\mathrm{H}_{1} \quad$ : Faktor posisi dan lebar slotted blades tidak berpengaruh terhadap nilai koefisien daya..

Dari hasil pengujian yang dilakukan dilihat variabel mana yang memiliki pengaruh yang paling besar tehadap nilai $\mathrm{Cp}$ yang didapatkan. Hal ini dapat dilihat dari nilai signifikansi pada masing-masing variabel yang diuji.

\section{Hasil dan pembahasan}

Hasil eksperimen ditampilkan dalam Tabel 2. Pengujian ini merujuk pada penelitian sebelumnya yang dilakukan oleh (Harsito et al., 2020) dengan menggunakan prony brake system dan selanjutnya dianalisis sehingga didapatkan nilai $C p$.

Berdasarkan pengambilan data koefisen daya yang dilakukan secara konvensional telah berhasil dilaksanakan. Hasil penelitian ditampilkan pada Gambar 4. Gambar 4 menunjukkan bahwa nilai $\mathrm{Cp}$ pada konfigurasi posisi $20 \%$ dan lebar $3 \mathrm{~mm}$ memiliki nilai $\mathrm{Cp}$ yang maksimum yaitu 0,138. Nilai Cp pada penelitian ini lebih tinggi dibandingkan dengan penelitian sebelumnya dan juga penelitian tentang turbin angin savonius konvensional (Alaimo et al., 2013a).

Peningkatan $\mathrm{Cp}$ yang terjadi diakibatkan adanya penurunan gaya hambat pada sudu cembung yang menabrak angin. Angin yang menghambat putaran turbin ini berkurang dengan melewati celah yang dibuat pada bilah turbin (Alaimo et al., 2013a, 2012; Harsito et al., 2020). Berdasarkan Gambar 4 dapat dihat bahwa posisi slotted blades dan lebar celah mempengaruhi nilai $\mathrm{Cp}$. Hal ini dapat dibuktikan dengan menggunakan pengujian secara statistik.

Tabel 2

Data hasil eksperimen nilai $C p$

\begin{tabular}{lllll}
\hline Variasi & \multicolumn{3}{l}{ Posisi Slotted Blades } & \multicolumn{2}{c}{ Standar } \\
\cline { 2 - 4 } & $20 \%$ & $30 \%$ & $40 \%$ & Deviasi \\
\hline \multirow{7}{*}{$3 \mathrm{~mm}$} & 0.138 & 0.083 & 0.066 & 0.038 \\
& 0.138 & 0.084 & 0.065 & 0.038 \\
& 0.144 & 0.085 & 0.066 & 0.041 \\
& 0.135 & 0.086 & 0.067 & 0.035 \\
$5 \mathrm{~mm}$ & 0.136 & 0.084 & 0.066 & 0.036 \\
\hline \multirow{5}{*}{5} & 0.102 & 0.078 & 0.042 & 0.030 \\
& 0.103 & 0.076 & 0.038 & 0.033 \\
& 0.102 & 0.074 & 0.038 & 0.032 \\
$7 \mathrm{~mm}$ & 0.101 & 0.076 & 0.038 & 0.032 \\
& 0.101 & 0.073 & 0.037 & 0.032 \\
\hline \multirow{7}{*}{5} & 0.096 & 0.072 & 0.036 & 0.030 \\
& 0.091 & 0.070 & 0.035 & 0.028 \\
& 0.092 & 0.069 & 0.035 & 0.029 \\
& 0.092 & 0.069 & 0.035 & 0.029 \\
& 0.093 & 0.067 & 0.035 & 0.029 \\
\hline
\end{tabular}

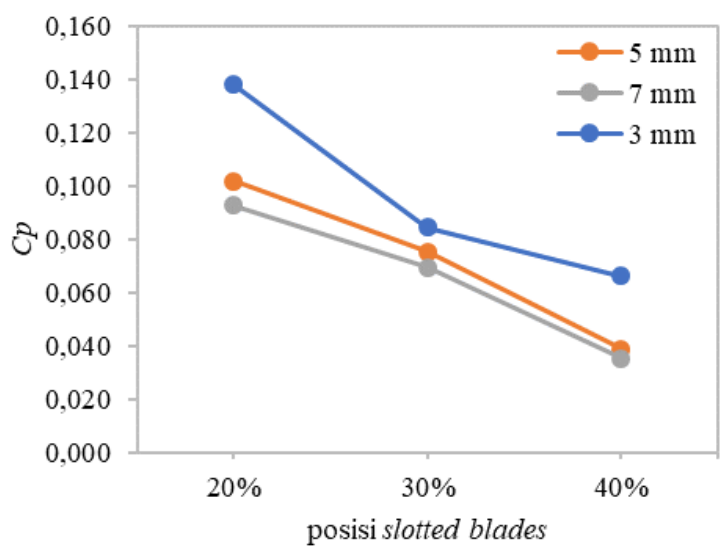

Gambar 4. Grafik hubungan antara posisi dan lebar celah slotted blades

\subsection{Normalitas data}

Sebelum dilakukan pengujian $A N O V A$, maka data yang dihasilkan harus diuji distribusi normalnya. Kolmogorov smirnov test adalah metode pengujian yang dilakukan menggunakan software SPSS dengan syarat bahwa data yang dihasilkan memiliki homogenitas data.

Berdasarkan data hasil pengujian homogenitas pada Tabel 3 dapat dilihat bahwa nilai signifikansi untuk koefisien daya adalah 0,266. Maka dapat disimpulkan bahwa data yang didapatkan pada pengujian ini memiliki variasi yang sama karena memiliki nilai signifikansi lebih dari 0,05 .

Uji normalitas Kolmogorov smirnov test dilakukan untuk melihat normalitas sebaran sebuah data. Berdasarkan hasil analisis yang telah dilakukan dengan metode Kolmogorov-Smirnov pada Tabel 4 dan Tabel 5 maka dapat disimpulkan bahwa data ini memiliki 
distribusi normal karena memiliki nilai signifikansi lebih besar dari 0,05 .

Tabel 3

Hasil uji homogenitas

\begin{tabular}{lllll}
\hline \multicolumn{4}{c}{ Koefisien Daya } \\
$\begin{array}{lllll}\text { Levene } \\
\text { Statistic }\end{array}$ & $\frac{d f 1}{2}$ & & $d f 2$ & Sig. \\
\cline { 1 - 1 }$\frac{\mathbf{1 , 3 6 8}}{2 \text { df adalah degree of freedom }}$ & & 42 & & $\mathbf{0 , 2 6 6}$ \\
\hline
\end{tabular}

Tabel 4

Hasil uji normalitas posisi slotted blades

\begin{tabular}{|c|c|c|c|c|}
\hline & \multirow{2}{*}{$\begin{array}{l}\text { Posisi } \\
\text { Slotted }\end{array}$} & \multicolumn{3}{|c|}{ Kolmogorov-Smirnov $^{a}$} \\
\hline & & Statistic & $d f$ & Sig. \\
\hline \multirow{3}{*}{$\begin{array}{l}\text { Coefficient } \\
\text { power }\end{array}$} & $20 \%$ & 0,318 & 15 & 0,000 \\
\hline & $30 \%$ & 0,176 & 15 & 0,200 \\
\hline & $40 \%$ & 0,326 & 15 & 0,000 \\
\hline
\end{tabular}

Tabel 5

Hasil uji normalitas lebar slotted blades

\begin{tabular}{|c|c|c|c|c|}
\hline & \multirow{2}{*}{ Lebar Slotted } & \multicolumn{3}{|c|}{ Kolmogorov-Smirnov $^{a}$} \\
\hline & & Statistic & $d f$ & Sig. \\
\hline \multirow{3}{*}{$\begin{array}{l}\text { Coefficient } \\
\text { power }\end{array}$} & $3 \mathrm{~mm}$ & 0,293 & 15 & 0,001 \\
\hline & $5 \mathrm{~mm}$ & 0,201 & 15 & 0,106 \\
\hline & $7 \mathrm{~mm}$ & 0,221 & 15 & 0,047 \\
\hline
\end{tabular}

\subsection{Pengaruh posisi dan lebar slotted blades}

Pengujian signifikansi untuk mengetahui pengaruh posisi dan lebar slotted blades dilakukan dengan uji ANOVA Unvariate. Setelah dilakukan beragam uji homogenitas dan normalitas sebagai syarat uji ANOVA. Tabel 6 menunjukkan hasil output uji $A N O V A$.

Tabel 6

Hasil output normalitas uji ANOVA (Levene's Test of Equality of Error Variancesa)

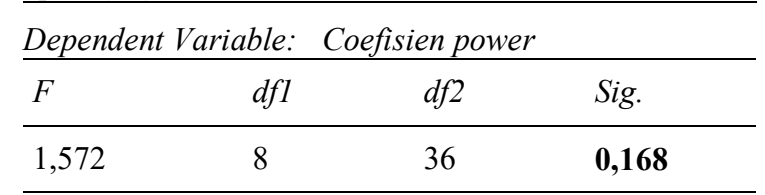

Tests the null hypothesis that the error variance of the dependent variable is equal across groups.

a. Design: Intercept + Posisi + Lebar + Posisi * Lebar

Berdasarkan output uji Levene's dapat diketahui bahwa masing-masing variasi dari variabel memiliki data variabel yang sama atau homogen karena memiliki nilai signifikansi 0,168 atau lebih dari 0,05. Karena data tersebut memiliki sifat homogen maka syarat varian ini bisa dilakukan uji ANOVA sudah terpenuhi.

Pada Tabel 7 menunjukkan hasil Tests of BetweenSubjects Effects ANOVA dengan nilai F-0 atau nilai signifikansi. Berdasarkan nilai signifikansi yang ada yaitu 0,000 kurang dari 0,05 maka $\mathrm{H} 0$ diterima atau bisa dikatakan bahwa lebar slotted blades berpengaruh terhadap nilai $\mathrm{Cp}$. Hal ini juga bisa dilihat berdasarkan nilai F-0 yang lebih besar dari $F_{\text {crit }}$ maka dapat disimpulkan bahwa konfigurasi lebar penelitian ini berpengaruh terhadap nilai $\mathrm{Cp}$. Selain itu pada hipotesis kedua, karena nilai signifikansi pada variasi posisi memiliki nilai 0,000 kurang dari 0,05 maka $\mathrm{H} 0$ diterima atau bisa disimpulkan bahwa posisi slotted blades berpengaruh terhadap nilai $\mathrm{Cp}$. Pada output Posisi*Lebar dapat dilihat bahwa nilai signifikansi sebesar 0,000 kurang dari 0,05 sehingga dapat disimpulkan bahwa tidak ada interaksi antara kedua variasi ini.

Tabel 7

Hasil Tests of Between-Subjects Effects ANOVA

\begin{tabular}{llllll}
\hline \multicolumn{5}{c}{ Dependent Variable: } & Coefisien power \\
\hline Source & $\begin{array}{l}\text { Sum of } \\
\text { Squares }\end{array}$ & $d f$ & $\begin{array}{l}\text { Mean } \\
\text { Square }\end{array}$ & $F$ & Sig. \\
\hline $\begin{array}{l}\text { Corrected } \\
\text { Model }\end{array}$ & $0,040^{\mathrm{a}}$ & 8 & 0,005 & 1536,74 &, 000 \\
Intercept & 0,274 & 1 & 0,274 & 83478,51 &, 000 \\
Posisi & 0,031 & 2 & 0,016 & $\mathbf{4 7 4 3 , 5 8}$ &, 000 \\
Lebar & 0,008 & 2 & 0,004 & $\mathbf{1 1 8 2 , 6 9}$ &, 000 \\
Posisi $*$ Lebar & 0,001 & 4 & 0,000 & $\mathbf{1 1 0 , 3 5}$ &, 000 \\
Error & 0,000 & 36 & $3,278 \mathrm{e}-6$ & & \\
Total & 0,314 & 45 & & & \\
Corrected Total & 0,040 & 44 & & \\
\hline a. $R$ Squared $=, 997$ (Adjusted $R$ Squared $=, 996)$ \\
Tabel 8
\end{tabular}

Tabel 9

Output $A N O V A$ regresi linier

\begin{tabular}{llllll}
\hline Model & $\begin{array}{l}\text { Sum of } \\
\text { Squares }\end{array}$ & $d f$ & $\begin{array}{l}\text { Mean } \\
\text { Square }\end{array}$ & $F$ & Sig. \\
\hline Regression & 0,038 & 2 & 0,019 & 326,415 & $\mathbf{0 , 0 0 0}^{\mathbf{b}}$ \\
1 Residual & 0,002 & 42 & 0,000 & & \\
\multicolumn{1}{c}{ Total } & 0,040 & 44 & & \\
\hline a. Dependent Variable: Coefisien power \\
b. Predictors: (Constant), Lebar Slotted, Posisi Slotted
\end{tabular}

Setelah penggunaan uji hipotesis ANOVA unvariated menunjukkan hasil maka untuk memperkuat hasil hipotesis dapat dilakukan uji hipotesis ANOVA linier. Tabel 8 merupakan output summary regresi linier menunjukkan nilai $\mathrm{R}$ yang memiliki arti hubungan interaksi antara lebar dan posisi slotted blades terhadap nilai koefisien daya adalah 0,969 sedangkan nilai determinan $\mathrm{R}^{2}$ sama dengan 0,940 yang berarti bahwa lebar*posisi slotted blades memiliki pengaruh 94\% terhadap nilai koefisen daya.

Output regresi linier ANOVA ditunjukkan pada Tabel 9 yang menunjukkan interprestasi interaksi antara posisi dengan lebar slotted blades. Nilai signifikansi 0,000 yang dihasilkan dari output uji ANOVA memiliki nilai kurang dari 0,05 maka dapat disimpulkan bahwa interaksi antara posisi dan lebar slotted blades 
mempengaruhi terhadap nilai koefisien daya $(C p)$. Pada Tabel 10 menunjukkan nilai output koefisien regresi linier dengan pengaruh posisi dan lebar slotted blades. Berdasarkan nilai output pada Tabel 10 maka nilai regresi linier dapat dirumuskan sebagai berikut:

$$
Y=0,173-0,032 x_{1}-0,015 x_{2}
$$

Tabel 10

Output koefisien regresi linier

\begin{tabular}{|c|c|c|c|c|c|}
\hline \multirow{2}{*}{ Model } & \multicolumn{2}{|c|}{$\begin{array}{l}\text { Unstandardized } \\
\text { Coefficients }\end{array}$} & \multirow{2}{*}{$\begin{array}{l}\text { Stand. } \\
\text { Coeff. } \\
\text { Beta }\end{array}$} & \multirow{2}{*}{$t$} & \multirow{2}{*}{ Sig. } \\
\hline & $B$ & $\begin{array}{l}\text { Std. } \\
\text { Error }\end{array}$ & & & \\
\hline (Constant) & 0,173 & 0,004 & & 42,133 & 0,000 \\
\hline Posisi Slotted & $-0,032$ & 0,001 & $-0,876$ & $-23,101$ & 0,000 \\
\hline Lebar Slotted & $-0,015$ & 0,001 & $-0,414$ & $-10,916$ & 0,000 \\
\hline
\end{tabular}

a. Dependent Variable: Coefisien power

\subsection{Pengaruh variable terhadap nilai koefisien daya}

Menurut hasil output uji one-way ANOVA dapat diketahui variabel yang paling berpengaruh diantara posisi dan lebar slotted blades terhadap nilai koefisien daya dengan membandingkan nilai signifikansi.

Tabel 11 menunjukkan hasil output uji one-way ANOVA dengan nilai signifikansi 0,000 sehingga dapat disimpulkan bahwa posisi slotted blades mempunyai pengaruh terhadap nilai koefisien daya karena nilai signifikansi kurang dari 0,05 sehingga H0 diterima.

Tabel 11

Hasil output one-way ANOVA posisi slotted blades

\begin{tabular}{llllll}
\hline Coefisien power "posisi slotted blades & & & \\
\cline { 2 - 6 } & $\begin{array}{l}\text { Sum of } \\
\text { Squares }\end{array}$ & df & $\begin{array}{l}\text { Mean } \\
\text { Square }\end{array}$ & $F$ & Sig. \\
\hline Between Groups & 0,031 & 2 & 0,016 & 70,082 & $\mathbf{0 , 0 0 0}$ \\
Within Groups & 0,009 & 42 & 0,000 & & \\
Total & 0,040 & 44 & & & \\
\hline
\end{tabular}

Berdasarkan hasil output one-way ANOVA posisi slotted blades yang ditampilkan pada Tabel 12 dapat disimpulkan bahwa posisi slotted blades berpengaruh terhadap nilai koefisien daya karena nilai signifikansi 0,011 kurang dari 0,05 sehingga $\mathrm{H} 0$ diterima.

Tabel 12

Hasil output one-way ANOVA posisi slotted blades

\begin{tabular}{llllll}
\hline Coefisien power 'lebar slotted blades & & & \\
\cline { 2 - 6 } & $\begin{array}{l}\text { Sum of } \\
\text { Squares }\end{array}$ & $d f$ & $\begin{array}{l}\text { Mean } \\
\text { Square }\end{array}$ & $F$ & Sig. \\
\hline Between Groups & 0,008 & 2 & 0,004 & 4,985 & $\mathbf{0 , 0 1 1}$ \\
Within Groups & 0,033 & 42 & 0,001 & & \\
Total & 0,040 & 44 & & & \\
\hline
\end{tabular}

Dilihat berdasarkan nilai signifikansi dari masingmasing variabel yang dihasilkan yaitu dengan demikian kesimpulan yang didapatkan adalah variabel posisi dan lebar slotted blades berpengaruh terhadap nilai koefisien daya. Variabel posisi slotted blades merupakan variabel yang paling berpengaruh terhadap nilai koefisien daya karena nilai signifikansinya lebih kecil dari lebar slotted blades yaitu 0,000 kurang dari 0,011 yang menandakan bahwa ikatannya tidak kuat.

\section{Kesimpulan}

Serangkaian uji yang telah dilakukan dalam penelitian ini menghasilkan beberapa kesimpulan yaitu terdapat pengaruh lebar slotted blades yang signifikan terhadap nilai koefisien daya (Sig. 0,011 kurang dari 0,05). Lebar dan posisi slotted blades memiliki pengaruh yang signifikan terhadap nilai koefisien daya (Sig. 0,000 kurang dari 0,05). Variabel posisi slotted blades merupakan variabel yang paling berpengaruh terhadap nilai koefisien daya karena nilai signifikansinya lebih kecil dari lebar slotted blades yaitu 0,000 kurang dari 0,011 .

\section{Daftar pustaka}

Akhmad, K., 2005. Pembangkit listrik tenaga surya dan penerapannya untuk daerah terpencil. Jurnal Ilmiah Dinamika Rekayasa 1, 28-33. https://doi.org/10. 20884/1.dr.2005.1.1.8

Akwa, J.V., Vielmo, H.A., Petry, A.P., 2012. A review on the performance of Savonius wind turbines. Renewable and Sustainable Energy Reviews 16, 3054-3064. https://doi.org/10.1016/J.RSER.2012. 02.056

Al Sadi, J., 2018. Designing experiments: 3 level full factorial design and variation of processing parameters methods for polymer colors. Advances in Science, Technology and Engineering Systems 3, 109-115. https://doi.org/10.25046/aj030515

Alaimo, A., Esposito, A., Milazzo, A., Orlando, C., Trentacosti, F., 2013a. Slotted blades savonius wind turbine analysis by CFD. Energies 6, 6335-6351. https://doi.org/10.3390/en6126335

Alaimo, A., Esposito, A., Milazzo, A., Orlando, C., Trentacosti, F., Universitaria, C., 2013b. Slotted blades Savonius wind turbine analysis by CFD. Energies 6, 6335-6351. https://doi.org/10.3390/ en6126335

Alaimo, A., Milazzo, A., Trentacosti, F., Esposito, A., 2012. On the effect of slotted blades on Savonius wind generator performances by CFD analysis. Advanced Materials Research 512-515, 747-753. https://doi.org/10.4028/www.scientific.net/AMR.512 $-515.747$

Arifianto, F., Saleh, M., Anisa, 2014. Identifikasi faktor signifikan pada rancangan faktorial fraksional dan 10, 92-101.

Harsito, C., Tjahjana, D.D.D.P., Kristiawan, B., 2020. Savonius turbine performance with slotted blades. AIP Conference Proceedings 2217, 30071. https://doi.org/10.1063/5.0000797

Jha, A.R., 2010. Wind turbine technology. CRC press, 
London.

Mangedaby, E.A., Setioko, B., Sari, S.R., 2017. Pengaruh desa wisata kampoeng batik laweyan terhadap fungsi permukiman di kelurahan laweyan Kota Surakarta. Teknik 38, 28. https://doi.org/10.14710/teknik.v38i1.12057

Montelpare, S., D’Alessandro, V., Zoppi, A., Ricci, R., 2018. Experimental study on a modified Savonius wind rotor for street lighting systems. Analysis of external appendages and elements. Energy 144, 146158. https://doi.org/10.1016/J.ENERGY.2017.12.017

Montgomery, D.C., 2017. Design and analysis of experiments. John wiley \& sons.

Morshed, K., 2010. Experimental and numerical investigations on aerodynamic characteristics of Savonius wind turbine with various overlap ratios. Electronic Theses \& Dissertations.

Nugroho, A., 2013. Perencanaan kapasitas pembangkit PLTM sungai logung karangtalun Kabupaten Temanggung. Teknik 34, 170-173. https://doi.org/10.14710/teknik.v34i3.6721

Prasetyo, Y., Bashit, N., 2018. Analisis tingkat akurasi model tiga dimensi gedung Prof . H . Soedarto Sh . menggunakan teknologi Terrestrial Laser Scanner ( Tls ) berbasis metode traverse. Teknik 39, 94-98. https://doi.org/10.14710/teknik.v39n2.17883

Rahman, M.M., Pal, A., Uddin, K., Thu, K., Saha, B.B., 2018. Statistical analysis of optimized isotherm model for maxsorb III/ethanol and silica gel/water pairs. Evergreen 5, 1-12. https://doi.org/10.5109/ 2174852

Ramadhan, A.I., Diniardi, E., Mukti, S.H., 2016. Analisis desain sistem pembangkit listrik tenaga surya kapasitas 50 WP. Teknik 37, 59. https://doi.org/10.14710/teknik.v37i2.9011

Salomon, L.L., Kosasih, W., Angkasa, S.O., 2017. Perancangan eksperimen untuk meningkatkan kualitas ketangguhan material dengan pendekatan analisis general factorial design (Studi Kasus: Produk Solid Surface). Jurnal Rekayasa Sistem Industri 4, 20. https://doi.org/10.26593/jrsi.v4i1.1386.20-26

Tian, W., Mao, Z., Zhang, B., Li, Y., 2018. Shape optimization of a Savonius wind rotor with different convex and concave sides. Renewable Energy 117, 287-299. https://doi.org/10.1016/j.renene.2017. 10.067

Tjahjana, D.D.D.P., Arifin, Z., Suyitno, S., Juwana, W.E., Prabowo, A.R., Harsito, C., 2021. Experimental study of the effect of slotted blades on the Savonius wind turbine performance. Theoretical and Applied Mechanics Letters 100249. https://doi.org/https://doi.org/10.1016/j.taml.2021.10 0249

Yang, B., Lawn, C., 2011. Fluid dynamic performance of a vertical axis turbine for tidal currents. Renewable Energy 36, 3355-3366. https://doi.org/10.1016/J.RENENE.2011.05.014 